Article

\title{
Phylogeography of Rattus norvegicus in the South Atlantic Ocean
}

\author{
Melanie Hingston ${ }^{1, *}$, Sally Poncet ${ }^{2}$, Ken Passfield ${ }^{3}$, Michael A. Tabak ${ }^{4,5}$, Sofia I. Gabriel ${ }^{6}$, \\ Stuart B. Piertney ${ }^{7}$ and James C. Russell ${ }^{1}$ \\ 1 School of Biological Sciences, University of Auckland, Private Bag 92019, Auckland 1142, New Zealand; \\ j.russell@auckland.ac.nz \\ 2 Antarctic Research Trust, P.O. Box 685, Stanley FIQQ 1ZZ, Falkland Islands; sallyponcet@horizon.co.fk \\ 3 Beaver Island LandCare, P.O. Box 538, Stanley FIQQ 1ZZ, Falkland Islands; kenpassfield@gmail.com \\ 4 Zoology \& Physiology Department, University of Wyoming, 1000 E. University Ave, \\ Laramie, WY 82071, USA; tabakma@gmail.com \\ 5 Quantitative Science Consulting, LLC, 765 N. 10th St., Laramie, WY 82072, USA \\ 6 CESAM-Centre for Environmental and Marine Studies, Departamento de Biologia Animal, \\ Faculdade de Ciências da Universidade de Lisboa, Lisbon 1749-016, Portugal; sofiagabriel@gmail.com \\ 7 Institute of Biological and Environmental Sciences, University of Aberdeen, Aberdeen AB24 2TZ, UK; \\ s.piertney@abdn.ac.uk \\ * Correspondence: melanie.hingston@auckland.ac.nz; Tel.: +64-9-923-8745
}

Academic Editor: Paulo A. V. Borges

Received: 14 October 2016; Accepted: 12 December 2016; Published: 20 December 2016

\begin{abstract}
Norway rats are a globally distributed invasive species, which have colonized many islands around the world, including in the South Atlantic Ocean. We investigated the phylogeography of Norway rats across the South Atlantic Ocean and bordering continental countries. We identified haplotypes from $517 \mathrm{bp}$ of the hypervariable region I of the mitochondrial D-loop and constructed a Bayesian consensus tree and median-joining network incorporating all other publicly available haplotypes via an alignment of $364 \mathrm{bp}$. Three Norway rat haplotypes are present across the islands of the South Atlantic Ocean, including multiple haplotypes separated by geographic barriers within island groups. All three haplotypes have been previously recorded from European countries. Our results support the hypothesis of rapid Norway rat colonization of South Atlantic Ocean islands by sea-faring European nations from multiple European ports of origin. This seems to have been the predominant pathway for repeated Norway rat invasions of islands, even within the same archipelago, rather than within-island dispersal across geographic barriers.
\end{abstract}

Keywords: commensals; invasive species; island phylogeography; mitochondrial DNA; pest management; Rattus norvegicus; South Atlantic

\section{Introduction}

The Norway rat (brown rat, Rattus norvegicus Berkenhout 1769) is globally distributed and recognised as an urban and agricultural pest species and a threat to biodiversity [1]. Originating from northern China, the species spread throughout the world in multiple waves [2] and has subsequently been dispersed since the 1500s by sea-faring nations to far-flung islands around the world [3]. In the South Atlantic Ocean, Norway rats are present on the cool temperate archipelago of the Falkland Islands and were present on the sub-Antarctic island of South Georgia prior to an eradication programme from 2011-2015. They co-exist with black rats (Rattus rattus Linnaeus, 1758) on the tropical islands of St Helena and Fernando de Noronha and potentially also on São Tomé and Príncipe in the Gulf of Guinea [4]. 
Examination of the patterns of genetic variation in a phylogeographic context can help identify the provenance of extant populations on individual islands. This can corroborate, or sometimes refute, historical human transportation routes [5], and simultaneously assist in developing rodent biosecurity and eradication programmes by identifying eradication units [6] and determining sources of reinvaders [7]. We analysed the phylogeography of Norway rats from several locations in both the North and South Atlantic Oceans in order to elucidate potential historical origin and to inform contemporary pest management for this invasive species.

\section{Materials and Methods}

Samples of Norway rats from the South Atlantic Ocean were collected at the Falkland Islands ( $n=49 ; 18$ locations in five areas), South Georgia $(n=8$; seven locations across two regions, previously identified as being genetically distinct [8]), Fernando de Noronha $(n=1)$ and the towns of Recife and Fortaleza on the coast of Brazil $(n=2)$ (Figure 1a). Additional samples $(n=4$; four locations from two regions) were obtained from mainland Portugal, the origin of the first maritime explorers to chart the South Atlantic Ocean and from Madeira island $(n=4 ; 3$ locations; Figure $1 \mathrm{~b})$, the first oceanic island colonized by the Portuguese and an important stop-over in the Atlantic during the European maritime expansion. Potential continental origin sites were determined from historical discovery and colonization records of islands. Additional sites were sampled from existing databases (China, Denmark, France, French Polynesia, Germany, Japan, Sweden, United Kingdom and USA; see below for GenBank Accession numbers). Tissue consisted of gastrocnemius muscle, tail clippings or liver biopsies, all stored in 70\% ethanol. Genomic DNA was extracted using a DNeasy Tissue Kit (Qiagen, Hilden, Germany) according to manufacturer's instructions. A 583 bp fragment containing the hypervariable region I (HVRI) of D-loop was PCR amplified in $30 \mu \mathrm{L}$ reactions containing $1 \mu \mathrm{L}$ extracted DNA, $2 \mathrm{mM} \mathrm{MgCl} 2,0.5 \mu \mathrm{M}$ each primer [9], $0.15 \mathrm{mM}$ dNTPs, $0.5 \mathrm{U}$ Platinum Taq polymerase (Invitrogen, Carlsbad, CA, USA) in $1 \times$ reaction buffer. PCR products were purified with DNA Clean \& Concentrator Kit (Zymo Research, Irvine, CA, USA) and eluted with buffer 3:1. DNA sequencing reactions and capillary separation was carried out on an ABI3730 DNA Analyser (Applied Biosystems, Foster City, CA, USA).

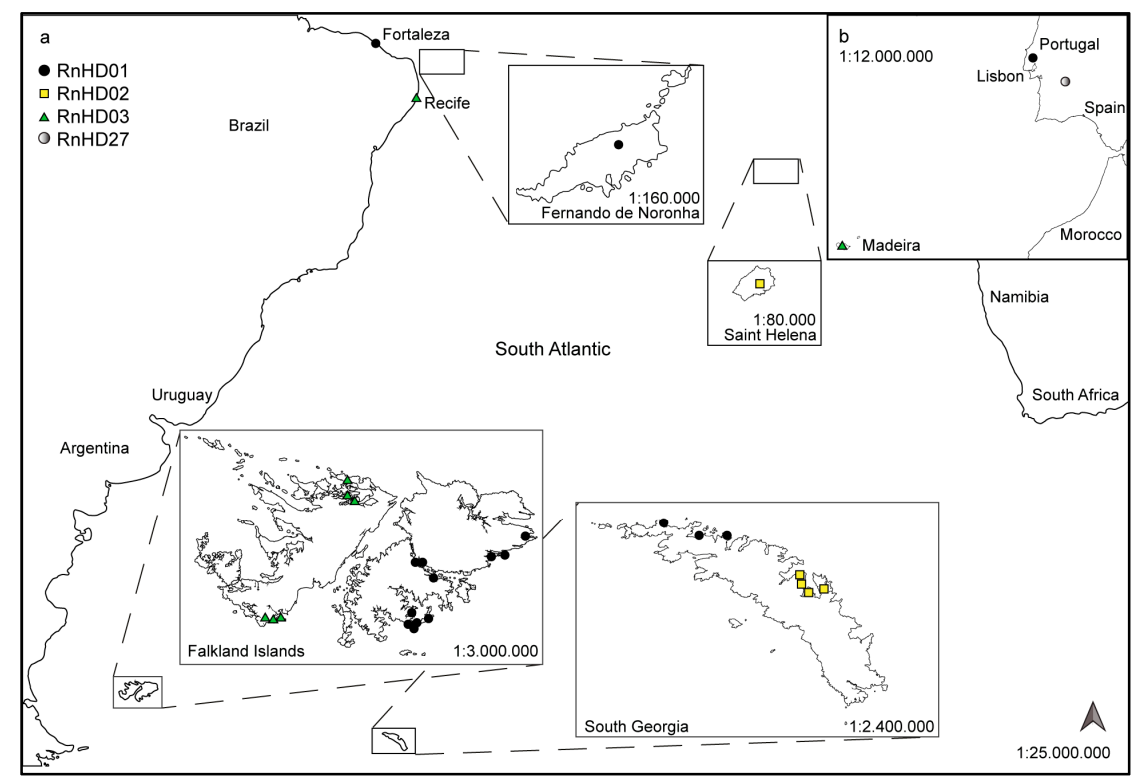

Figure 1. Map showing the sampling sites (a) within the South Atlantic Ocean. Areas of interest are magnified; (b) Inset covering sampling sites in Southern Portugal and Madeira. Colour codes for haplotypes of R. norvegicus are presented in (a). Both maps adapted after Esri, DeLorme, HERE and MapmyIndia. Additional sites were sampled from existing databases (not shown). 
The resulting sequences were aligned using the ClustalW algorithm in Geneious 9.1.5 (http:/ / www.geneious.com [10]) and confirmed by eye. Haplotypes were assigned and then combined with sequences of wild R. norvegicus from GenBank-AJ428514 [11]; DQ673916-17 [12]; DQ897633-38 [13]; EF186346-347 [14]; FJ919756 [15]; HQ655891-915 [16]; JX887165-174 [17]. All sequences were truncated to $364 \mathrm{bp}$ to match the Haniza et al. [13] dataset as there was no loss of variability to the otherwise 499 bp long alignment. Shorter sequences from Kaleme, et al. [18] and Usdin, et al. [19] were not included. The full list of samples and locations is available in Table S1 of Supplementary. A Bayesian inference tree was calculated in MrBayes (plugin version 2.2.2. for Geneious [20,21]) with four heated MCMC chains over 5,000,000 iterations, sampling every 1000th tree. A burn-in of $10 \%$ was discarded after visual inspection of the trace file for convergence. An effective sampling size of over 4000 samples was reached. $R$. rattus and Rattus exulans (Peale, 1848) sequences from the sister haplogroup of $R$. norvegicus were used as combined outgroup. A median joining network was constructed in PopART1.7 [22].

\section{Results}

Two haplotypes were found in the Falkland Islands (Figure 1), strictly separated by location: RnHD01 (R. norvegicus Haplotype D-loop) was found on the main island of East Falkland and its eastern offshore islands, and RnHD03 on islands close to the main island of West Falkland (with the assumption made that this haplotype is also present on the main island of West Falkland, see [23]). Both haplotypes were also present in the towns of Fortaleza (RnHD01) and Recife (RnHD03) on the Brazilian mainland, while RnHD01 was found on the Brazilian island of Fernando de Noronha. A divide was also present on South Georgia, with RnHD01 at the northwest end of the island and RnHD02 at locations across the southeast end of the island. Haplotype RnHD02 was found on the British overseas territory island of St Helena. In Portugal RnHD01 was found at three locations around Lisbon while a new haplotype, RnHD27 (a sister haplotype to RnHD02), was found further inland, and RnHD03 was found on the Portuguese island of Madeira.

The phylogenetic tree (Figure 2), based on the currently publicly available data for R. norvegicus (D-loop), revealed three intraspecific well supported clades with posterior probabilities (PP) higher than 0.9. One clade contains samples from China only (III), while the other two clades contain the two haplotypes found in the Falkland Islands (I \& II) and northwestern South Georgia (I). The West Falkland haplotype RnHD03 is known to be abundant in Germany and France [17] and the East Falkland haplotype RnHD01, which is also present in the northwest region of South Georgia, is abundant in the United Kingdom [13]. Haplotype RnHD02 (closely related to RnHD03, but not within its clade), is found in the southeast region of South Georgia, frequently found in the United Kingdom and further present in Denmark [11,13] (Figures 2 and 3).

The currently known mutational relationship (median joining) among Norway rat haplotypes and their geographic distribution among all countries where sources are available is depicted in the network (Figure 3, based on the same dataset as the phylogenetic tree; differences in sample size due to many different sources visualised). The network revealed the positioning of the haplotypes found in the South Atlantic at opposite ends. The centre is formed by haplotypes found in China with as many mutational steps among Chinese $R$. norvegicus as between RnHD01 and RnHD03 found in the Falkland Islands. 


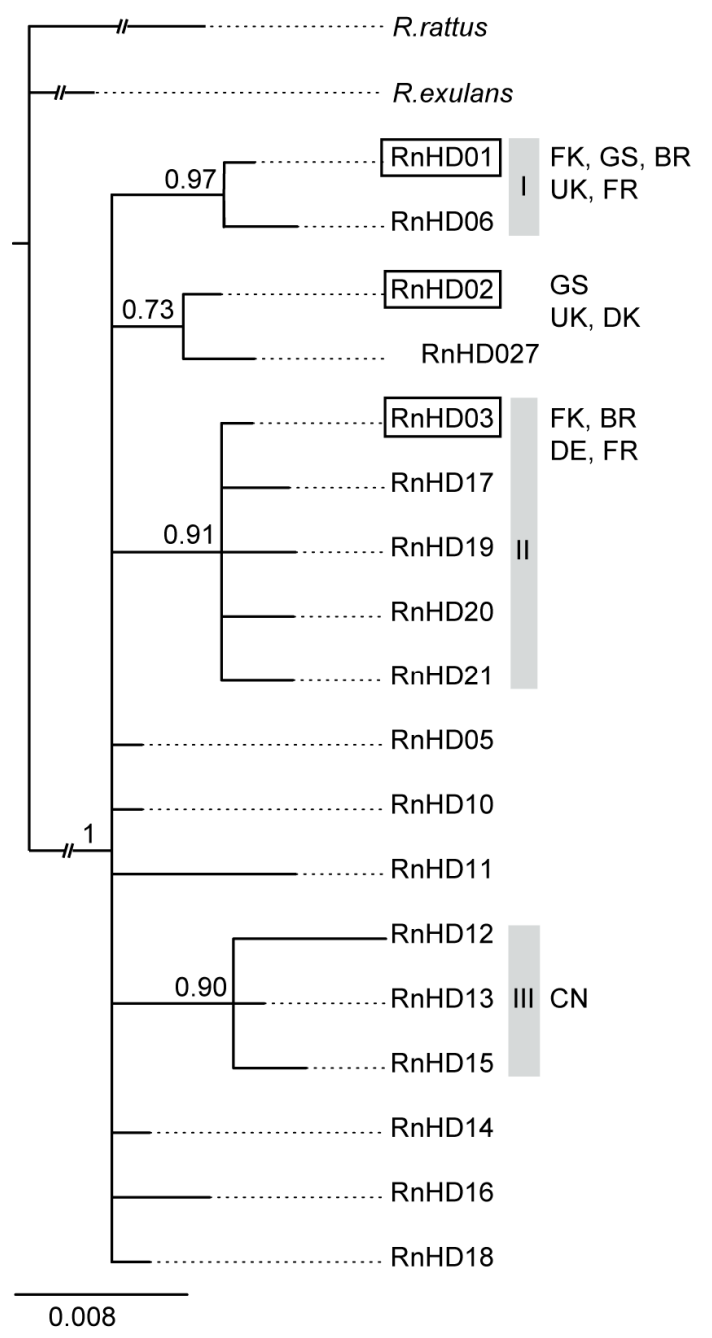

Figure 2. Bayesian consensus tree derived from $18 \mathrm{mtDNA}$ D-loop haplotypes of $R$. norvegicus, rooted by $R$. rattus and $R$. exulans (broken lines indicate shortening of branches for better fit). Haplotypes from the South Atlantic highlighted by boxes, with locations in this study and highest abundance outside of the Atlantic indicated by ISO 3166-2 code (http://www.iso.org/iso/country_codes), also refer to legend in Figure 3. Posterior probabilities (PP) $>0.7$ are shown on branches, clades with PP $>0.9$ highlighted by numbered grey bars. Scale bar indicates number of substitutions per site. 


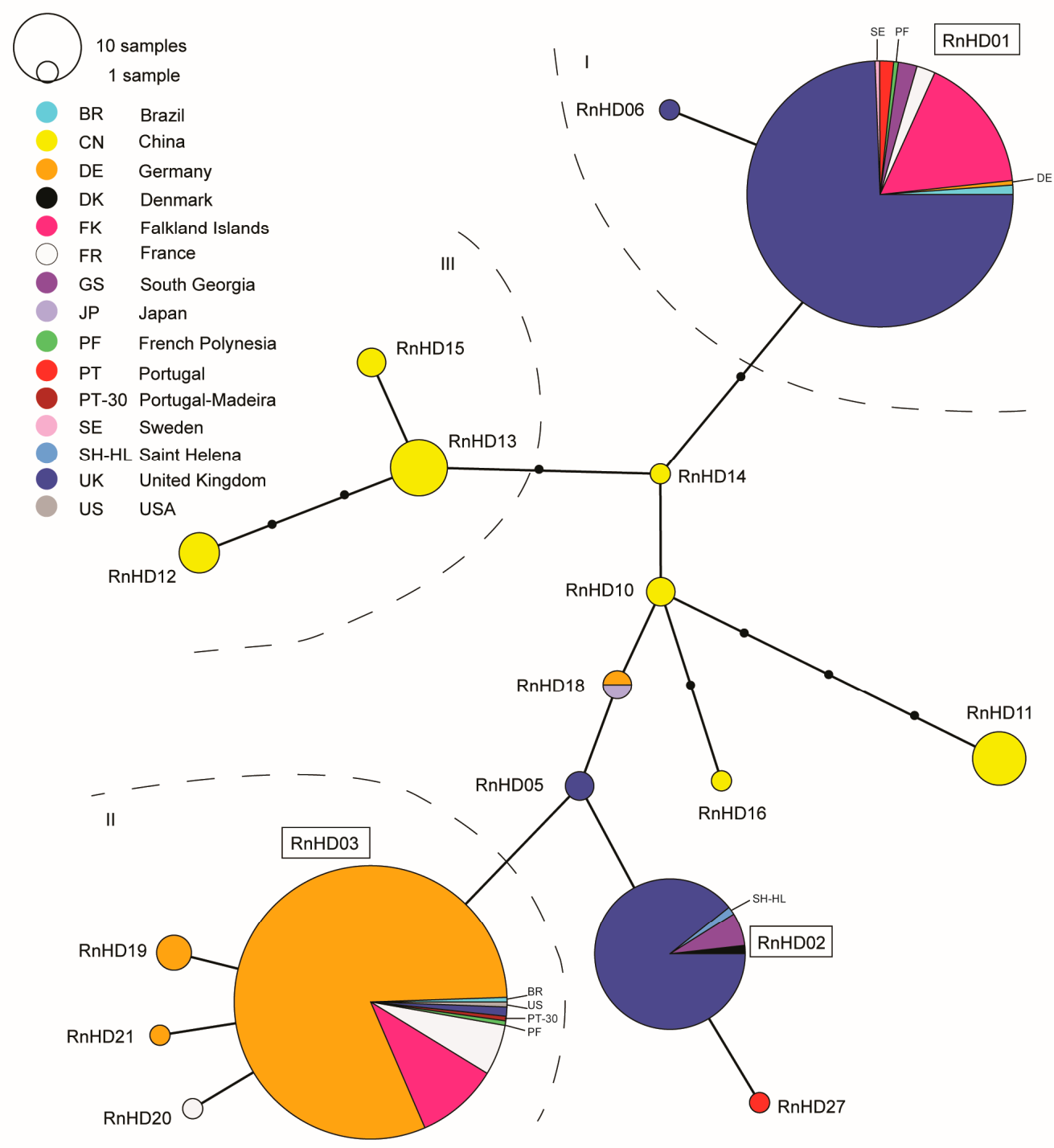

Figure 3. Median Joining network of $17 \mathrm{mtDNA}$ D-loop haplotypes of R. norvegicus (364 bp; indel not distinguished; 1-step-edges shown). Diameter indicates abundance among 451 samples from this study and GenBank sequences. Haplotypes found in the South Atlantic are highlighted by boxes, supported clades within the Bayesian consensus tree circled and numbered corresponding to Figure 2. Locations indicated by ISO 3166-2 code (http:/ / www.iso.org/iso/country_codes) and smallest wedges annotated within network.

\section{Discussion}

The match across the South Atlantic islands between the three Norway rat haplotypes (RnHD01, RnHD02, and RnHD03) with known European haplotypes indicate that the rat populations on these islands most likely originated in Europe, as would historically be expected. The variation within archipelagos (e.g., within the Falkland Islands) and even within islands (e.g., within South Georgia) indicates that these regions most likely were invaded in multiple events at spatially segregated sites. This same pattern has also been observed multiple times in island studies examining the human-mediated colonization history of the house mouse, Mus musculus (e.g., [24,25]).

Variation in the haplotypes of Norway rats from Europe have been previously documented from northern and central Europe [2], but haplotypes from Portugal have not previously been described. These haplotypes are particularly important as the Portuguese were the first European explorers and colonizers of the tropical South Atlantic islands from Africa to Brazil, and thus the most likely initial 
source of rats invading all these locations. We found the haplotypes in Portugal matched those of neighbouring Iberian Peninsula locations (i.e., Spain and southern France [26]). Molecular data (SNPs within D-loop, not covering all variability across D-loop) from South American Norway rats [2] also appear to correspond to D-loop haplotypes RnHD02 (Argentina) and RnHD06 (Brazil), the latter being a sister to RnHD01 and also found throughout the UK.

In all our sampling locations in the South Atlantic the Norway rat haplotypes found could be matched with those of the origin location of early colonists; Recife (Dutch), Fortaleza (Portuguese), Fernando de Noronha (Portuguese), West Falkland (British), East Falkland (French). This was also the case for South Georgia northwest region (British: the first vessel here was likely British, in the 1780s, closely followed by American sealing vessels from Nantucket, New England), and South Georgia southeast region (the first vessels here, also American and British sealers in the 1780s, are known to have introduced rats to the Grytviken area; a further introduction occurred in 1905, when rats from the vessel Guardia National were documented on shore at the jetty of the new Grytviken whaling station, after landing cargo from Buenos Aires, Argentina). These rats today most likely still represent the original colonists, as invasive rats typically resist secondary invasions [27].

Norway rats are capable dispersers across land and across at least $1 \mathrm{~km}$ of water (e.g., [23]), but certain geographical features pose barriers to dispersal. For example, the glaciers of South Georgia Island (e.g., [6,8]), and the waters of Falkland Sound that separate East Falkland and West Falkland, have evidently proved to be impassable barriers to Norway rat dispersal. Norway rats appear to have invaded opposite sides of these barriers instead by independent long-distance sea-faring dispersal, of different haplotypes, potentially from alternative European ports of origin. Evidently, Norway rats have been introduced multiple times to islands of the South Atlantic and, having been limited by barriers, have not spread far beyond their origins.

Norway rats can colonize islands rapidly following arrival (e.g., [28]) and disperse among them [29], so we propose that the multiple invasions of these South Atlantic islands originated from distant locations in continental Europe following the development of long-distance seafaring at the end of the 1400s. The similarity in Norway rat haplotypes among all islands of the South Atlantic Ocean also suggests it was a rapid dispersal of Norway rats from Europe to the different island groups, before human-assisted dispersal within island groups could take place across geographic barriers. The Norway rats on Madeira share a northern European origin, which has also been identified in house mice [30], but extensive sampling of Norway rats from the neighbouring island archipelagos of the Azores, Canaries and Cape Verde is required to place this North Atlantic result in a wider phylogeographic context alongside our South Atlantic results. Such efforts would be well supported by the use of finer resolution molecular technologies (e.g., SNPS [2,8]).

Supplementary Materials: The following are available online at www.mdpi.com/1424-2818/8/4/32/s1, Table S1: Sample information.

Acknowledgments: Funding for sample collection was provided by the Shackleton Scholarship Fund, Antarctic Research Trust, the Wyoming Biodiversity Institute, PVE/CAPES (Proposal 235453) and Fundação para a Ciência e a Tecnologia (SFRH/BPD/88854/2012). Thanks to Martin Collins, Andy Black, Darren Christie and the Government of South Georgia and South Sandwich Islands for the provision of samples from South Georgia, Annalea Beard for providing the rat sample from St Helena Island, Joaquim Tapisso, Rita Monarca and Ana Cerveira for samples from Portugal, and Emily Puckett for help validating South American SNP haplotypes. Funding for DNA sequencing was provided by Island LandCare, the University of Auckland. Thanks to two anonymous reviewers for the constructive comments.

Author Contributions: S.P. and J.C.R. conceived the research; J.C.R., S.P., K.P., M.A.T. and S.I.G. collected the data; M.H., S.I.G. and S.B.P. carried out laboratory analyses; M.H. analysed the data; and J.C.R. and M.H. led the writing.

Conflicts of Interest: The authors declare no conflict of interest. 


\section{References}

1. Aplin, K.P.; Chesser, T.; Have, J.T. Evolutionary biology of the genus Rattus: Profile of an archetypal rodent pest. ACIAR Monogr. Ser. 2003, 96, 487-498.

2. Puckett, E.E.; Park, J.; Combs, M.; Blum, M.J.; Bryant, J.E.; Caccone, A.; Costa, F.; Deinum, E.E.; Esther, A.; Himsworth, C.G.; et al. Global population divergence and admixture of the brown rat Rattus norvegicus. Proc. R. Soc. B Biol. Sci. 2016, 283. [CrossRef] [PubMed]

3. Atkinson, I.A.E. The spread of commensal species of Rattus to oceanic islands and their effects on island avifaunas. In Conservation of Island Birds; ICBP Technical Publication No. 3; Moors, P.J., Ed.; International Council for Bird Preservation: Cambridge, UK, 1985; pp. 35-81.

4. Dutton, J. Introduced mammals in São Tomé and Príncipe: Possible threats to biodiversity. Biodivers. Conserv. 1994, 3, 927-938. [CrossRef]

5. Jones, E.P.; Eager, H.M.; Gabriel, S.I.; Jóhannesdóttir, F.; Searle, J.B. Genetic tracking of mice and other bioproxies to infer human history. Trends Genet. 2013, 29, 298-308. [CrossRef] [PubMed]

6. Robertson, B.C.; Gemmell, N.J. Defining eradication units to control invasive pests. J. Appl. Ecol. 2004, 41, 1042-1048. [CrossRef]

7. Abdelkrim, J.; Pascal, M.; Samadi, S. Establishing causes of eradication failure based on genetics: Case study of ship rat eradication in Ste. Anne archipelago. Conserv. Biol. 2007, 21, 719-730. [CrossRef] [PubMed]

8. Piertney, S.B.; Black, A.; Watt, L.; Christie, D.; Poncet, S.; Collins, M.A. Resolving patterns of population genetic and phylogeographic structure to inform control and eradication initiatives for brown rats Rattus norvegicus on South Georgia. J. Appl. Ecol. 2016, 53, 332-339. [CrossRef]

9. Matisoo-Smith, E.; Roberts, R.M.; Irwin, G.J.; Allen, J.S.; Penny, D.; Lambert, D.M. Patterns of prehistoric human mobility in Polynesia indicated by mtDNA from the Pacific rat. Proc. Nalt. Acad. Sci. USA 1998, 95, 15145-15150. [CrossRef]

10. Kearse, M.; Moir, R.; Wilson, A.; Stones-Havas, S.; Cheung, M.; Sturrock, S.; Buxton, S.; Cooper, A.; Markowitz, S.; Duran, C.; et al. Geneious Basic: An integrated and extendable desktop software platform for the organization and analysis of sequence data. Bioinformatics 2012, 28, 1647-1649. [CrossRef] [PubMed]

11. Nilsson, M.A.; Gullberg, A.; Spotorno, A.E.; Arnason, U.; Janke, A. Radiation of extant marsupials after the K/T boundary: Evidence from complete mitochondrial genomes. J. Mol. Evol. 2003, 57, S3-S12. [CrossRef] [PubMed]

12. Schlick, N.E.; Jensen-Seaman, M.I.; Orlebeke, K.; Kwitek, A.E.; Jacob, H.J.; Lazar, J. Sequence analysis of the complete mitochondrial DNA in 10 commonly used inbred rat strains. Am. J. Physiol. Cell Physiol. 2006, 291, C1183-C1192. [CrossRef] [PubMed]

13. Haniza, M.Z.H.; Adams, S.; Jones, E.P.; MacNicoll, A.; Mallon, E.B.; Smith, R.H.; Lambert, M.S. Large-scale structure of brown rat (Rattus norvegicus) populations in England: Effects on rodenticide resistance. PeerJ 2015, 3, e1458. [CrossRef] [PubMed]

14. Robins, J.H.; Hingston, M.; Matisoo-Smith, E.; Ross, H.A. Identifying Rattus species using mitochondrial DNA. Mol. Ecol. Notes 2007, 7, 717-729. [CrossRef]

15. Abhyankar, A.; Park, H.-B.; Tonolo, G.; Luthman, H. Comparative sequence analysis of the non-protein-coding mitochondrial DNA of inbred rat strains. PLoS ONE 2009, 4, e8148. [CrossRef] [PubMed]

16. Liu, J.; Liu, D.-Y.; Chen, W.; Li, J.-L.; Luo, F.; Li, Q.; Ling, J.-X.; Liu, Y.-Y.; Xiong, H.-R.; Ding, X.-H.; et al. Genetic analysis of hantaviruses and their rodent hosts in central-south China. Virus Res. 2012, 163, 439-447. [CrossRef] [PubMed]

17. Song, Y.; Lan, Z.; Kohn, M.H. Mitochondrial DNA phylogeography of the Norway rat. PLoS ONE 2014, 9 , e88425. [CrossRef] [PubMed]

18. Kaleme, P.; Bates, J.; Belesi, H.; Bowie, R.; Gambalemoke, M.; Kerbis-Peterhans, J.; Michaux, J.; Mwanga, J.; Ndara, B.; Taylor, P.; et al. Origin and putative colonization routes for invasive rodent taxa in the Democratic Republic of Congo. Afr. Zool. 2011, 46, 133-145. [CrossRef]

19. Usdin, K.; Chevret, P.; Catzeflis, F.M.; Verona, R.; Furano, A.V. Ll (LINE-1) retrotransposable elements provide a "fossil" record of the phylogenetic history of murid rodents. Mol. Biol. Evol. 1995, 12, 73-82. [CrossRef] [PubMed]

20. Huelsenbeck, J.P.; Ronquist, F.; Nielsen, R.; Bollback, J.P. Bayesian inference of phylogeny and its impact on evolutionary biology. Science 2001, 294, 2310-2314. [CrossRef] [PubMed] 
21. Ronquist, F.; Huelsenbeck, J.P. MrBayes 3: Bayesian phylogenetic inference under mixed models. Bioinformatics 2003, 19, 1572-1574. [CrossRef] [PubMed]

22. Leigh, J.W.; Bryant, D. PopART v1.7. Available online: http:// popart.otago.ac.nz (accessed on 12 July 2016).

23. Tabak, M.A.; Poncet, S.; Passfield, K.; Carling, M.D.; Martinez del Rio, C. The relationship between distance and genetic similarity among invasive rat populations in the Falkland Islands. Conserv. Genet. 2015, 16, 125-135. [CrossRef]

24. Jones, E.P.; Jensen, J.-K.; Magnussen, E.; Gregersen, N.; Hansen, H.S.; Searle, J.B. A molecular characterization of the charismatic Faroe house mouse. Biol. J. Linn. Soc. 2011, 102, 471-482. [CrossRef]

25. Gabriel, S.I.; Mathias, M.L.; Searle, J.B. Of mice and the "Age of Discovery": The complex history of colonization of the Azorean archipelago by the house mouse (Mus musculus) as revealed by mitochondrial DNA variation. J. Evol. Biol. 2015, 28, 130-145. [CrossRef] [PubMed]

26. Iacucci, A.; Colangelo, P.; Gamberi, V.; Mori, E.; Esther, A.; Baert, K.; Leirs, H.; Petit, T.; Ribas Salvador, A.; Aloise, G.; et al. Reconstructing the phylogeography of an invasive species: Tracing invasion routes of Norway rats (Rattus norvegicus) using mtDNA control region. Hystrix Ital. J. Mammol. 2016, 27, 5.

27. Fraser, C.I.; Banks, S.C.; Waters, J.M. Priority effects can lead to underestimation of dispersal and invasion potential. Biol. Invasions 2015, 17, 1-8. [CrossRef]

28. Russell, J.C.; Abdelkrim, J.; Fewster, R.M. Early colonisation population structure of a Norway rat island invasion. Biol. Invasions 2009, 11, 1557-1567. [CrossRef]

29. Russell, J.C.; Towns, D.R.; Anderson, S.H.; Clout, M.N. Intercepting the first rat ashore. Nature 2005, 437, 1107. [CrossRef] [PubMed]

30. Förster, D.W.; Gündüz, İ.; Nunes, A.C.; Gabriel, S.; Ramalhinho, M.G.; Mathias, M.L.; Britton-Davidian, J.; Searle, J.B. Molecular insights into the colonization and chromosomal diversification of Madeiran house mice. Mol. Ecol. 2009, 18, 4477-4494. [CrossRef] [PubMed]

(C) 2016 by the authors; licensee MDPI, Basel, Switzerland. This article is an open access article distributed under the terms and conditions of the Creative Commons Attribution (CC-BY) license (http://creativecommons.org/licenses/by/4.0/). 